\title{
Social (In)justice and Rental Housing Discrimination in Urban Canada: The Case of Ethno-racial Minorities in the Herongate Community in Ottawa
}

\author{
JOSEPH MENSAH \\ York University, Canada \\ DANIEL TUCKER-SIMMONS \\ Avant Law, Canada
}

\begin{abstract}
In 2015, the predominantly visible minority immigrant community of Herongate, in Ottawa, Ontario, was slated for redevelopment by its landlord, Timbercreek Asset Management. This redevelopment involved mass eviction of the incumbent tenants, demolition of the existing affordable housing and its replacement with luxury rentals, which, by all indications, are beyond the financial reach of the former Herongage tenants. This paper seeks to problematize large-scale residential real estate redevelopment in Canada and examine its impact, using the Herongate situation as a case study. Among other things, it profiles the Herongate community, its history and present redevelopment, and explores the legal framework, and the limits thereof, constraining mass evictions of this type in Ontario. The findings indicate that the selection of Herongate for redevelopment was not fortuitous; generally, racialized and immigrant communities like Herongate are disproportionately likely to be selected for large-scale redevelopment projects, and thus subjected to mass-evictions. Further results suggest that the dissolution of the Herongate community - and the attendant dislocation of its members - has exacted a pronounced social and economic toll and compounded the racial discrimination already experienced by the former Herongate residents, most of whom are visible minorities. The paper concludes with an appeal to imbue the redevelopment process with a greater regard for social justice, and a right to housing as a policy solution to address the injustice caused by real estate redevelopment.
\end{abstract}

KEYWORDS housing discrimination; mass evictions; social justice; gentrification; Ottawa 


\section{Introduction}

In his "Letter from America," written as a prologue to Danny Dorling's Injustice: Why Social Inequality Still Persists, Sam Pizzigati (2015) observes that "injustice envelopes us today and assaults us from every direction. We can't escape it. Injustice lurks everywhere we look, everywhere we click. Week by week, only the particulars change" (p. xiv). One such particular is what we grapple with in this paper: the mass eviction of a group of lowincome minority renters in the Herongate community in Ottawa. As Amartya Sen (2009) points out, "what moves us... is not the realization that the world falls short of being completely just... but that there are clearly remediable injustices around us which we want to eliminate" (p. vii; emphasis added). Convinced that some forms of injustice are remediable, this paper sheds light on the Herongate situation, and provides reasoned arguments to promote social justice in Canada's housing market, in general, and the Herongate community, in particular. The paper draws its theoretical insights from John Rawls's (1971) conception of social justice as fairness and Danny Dorling's (2015) analysis of why social inequality persist.

In 2015, the corporate landlord of the Herongate housing complex, Timbercreek Asset Management, began to implement a phased demolition of its properties in the Herongate community. The first phase, which began in 2015, affected some 80 units in Herongate (Kestler-D’Amours, 2018). A notice for the second, which was slated for 2018 and affected 150 units, was served on tenants by May of 2018, with the termination date of September 2018 (Kestler-D'Amours, 2018). By all indications, the notice complied with the minimum notice requirements and other obligations under the Residential Tenancies Act of Ontario. In fact, the tenants in the 150 units have all been evicted; the last ones left the complex in November 2018. Media accounts have it that the landlord wants to demolish the Herongate units mainly because, from the perspective of the landlord, the affected units are simply beyond repair (Schnurr, 2018). Couched in the theorization of social justice by Rawls (1971) and Dorling (2015), this paper examines the dynamics of housing discrimination and mass eviction, using the Herongate situation as its main point of departure. More specifically, we examine the causes and manifestations of housing discrimination in Canada, and explore whether the Herongate situation exemplifies the phenomenon or not. To the extent that the Herongate neighbourhood is an ethno-racial enclave, occupied mainly by visible minorities and Muslims, we synthesize the extant literature on the formation of ethnic enclaves, the (de)merits of living in ethnic enclaves, and how mass evictions affect people in such neighbourhoods and Herongate. Finally, we take on the issue of "a right to housing," and shed light on how mass evictions are regulated in Canada in the context of this human rights ethos.

There are a number of unique features about Herongate that make it particularly well suited for a case study of modern gentrification and housing 
discrimination in Canada. For one, the fact that the Herongate community is virtually coterminous with the StatsCan census tract 5050007.02 permits a detailed analysis of the ethno-racial facets of gentrification processes. In addition, Herongate's socio-economic composition makes it an archetypal example of an urban space that is susceptible to the encroachments of contemporary gentrification. It has a high density of people of colour $(70 \%)$, immigrants (52\%), and Muslims, and it is relatively poor. Further, unlike the dismantling of Africville and similar urban renewal projects of the 1960s and 1970s, which were state-led initiatives, the forced displacement of Herongate residents was driven entirely by a financialized, corporate landlord, a somewhat newer and understudied phenomenon in the Canadian urban context (Fields, 2014; Mensah, 2002).

Drawing on the extant literature as well as data from Herongate, the specific questions addressed in this paper include the following: What is housing discrimination, and what evidence is there to suggest that it occurs in Canada? How and why do ethnic enclaves form? What are the causes of large-scale evictions, and which parts of the city usually attract such fates? How does mass eviction affect its victims? To what extent are the existing Canadian regulations on mass evictions efficacious in addressing the Herongate situation? We intend to show that, indeed, Canadian cities, including Ottawa, are not immune to the phenomenon of housing discrimination, and that Blacks feature markedly among its victims. While the Herongate case study corroborates the extant literature on housing discrimination in Canada, as we shall soon see, it exhibits a clear novelty in dealing with people who are, simultaneously, vulnerable to discrimination from the standpoints of their race, religion, and social class. The mutually reinforcing nature of this triple-jeopardy of discrimination makes the Herongate situation highly detrimental to the lives of the victims. Also, while most of the previous studies deal with the experience of housing discrimination at the micro or individual level, at its core, the Herongate case is about the experience of housing discrimination at the macro or group level by way of mass eviction. Naturally, then, the ensuing discussion goes beyond matters of individual identity and individual justice to those of collective identity and social justice, thereby eliciting discourses of collective action, social resistance, and mass compensation.

In addition to providing much-needed advocacy, and attendant publicity, in support of those evicted from the Herongate community and others like them who are fighting against rental discrimination, the paper could serve as a handy backgrounder for social justice and public interest legal practitioners and advocates grappling with housing discrimination in Canada. Before examining the theoretical base of the study, the next section provides a brief overview of the Herongate community. 


\section{The Herongate Community in Ottawa: A Profile}

The Herongate neighbourhood is situated some seven kilometres south of downtown Ottawa and corresponds with census tract Number 5050007.02. The neighbourhood is bounded in the north and east by the community of Alta Vista, in the south by South Keys, and in the west by Ridgemont. According to the census, Herongate had a population of 4,681 in 2016, which represented some $0.35 \%$ of Ottawa's total population of $1,23,783$ at that time (Statistics Canada, 2016).

Beginning in the early 1990 s and continuing into the 2000 s, Herongate attracted an increasing number of immigrants and their families, particularly those of Somali origin fleeing civil war. From the 1990s until the present, Herongate was transformed incrementally into a predominantly immigrant community. Perhaps the most striking feature of the Herongate Community was the overwhelming presence of visible minorities. By 2016, as many as $70 \%$ of the residents in Herongate were visible minorities, compared to an overall visible minority proportion of $21.6 \%$ in Ottawa (Statistics Canada, 2016). According to the 2016 census, $30.9 \%$ of Herongate's resident were Blacks, 15.2\% were Arabs, and 11.8\% were South Asians; the comparable figures for Ottawa in general for these ethnic groups at the time were $6.0 \%$; $3.8 \%$, and $3.1 \%$, respectively. Additionally, by 2016 , more than half of Herongate's residents were immigrants, while only $19.7 \%$ of Ottawa's residents were immigrants (Statistics Canada 2016).

With such a high concentration of visible minorities and immigrants, it was not surprising that many Herongagte residents were of low-income background, with some $49.1 \%$ of them having incomes of under $\$ 40,000$ per year by the 2016 census, compared to $21.2 \%$ of Ottawa's residents who belonged to this income category then. Even though there is no data on housing quality in Herongate, anecdotal reports by the residents and the landlord suggest that much of the complex required major repairs or redevelopment entirely. Partly for this reason as well as others that are elaborated below, Herongate was also an affordable place to live, with significantly lower average rents than Alta Vista on its northern border as well as much of the rest of Ottawa. ${ }^{1}$

Some of the evicted Herongate tenants and other tenants from cognate properties owned by the same landlord, together with tenants from nearby properties owned by other landlords, have formed the Herongate Tenant Coalition (HTC) to resist the eviction, both through organizing efforts and through a legal application to the Ontario Human Rights Tribunal. A 2018 HTC census found that approximately 120 of the 150 townhouses slated for demolition were occupied, and provided housing for approximately 550

\footnotetext{
${ }^{1}$ The average rent statistics produced by the Canada Mortgage and Housing Corporation do not include specific statistics for Herongate. However, reports from 36 evicted tenants suggest that most Herongate residents either had to pay significantly higher rents or had to downsize when they moved to other areas of Ottawa.
} 
people, including some 200 children (HTC, 2018). Moreover, nearly $90 \%$ of the tenants captured by the HTC census were racial minorities, with Somali immigrants accounting for about 44\%; a significant proportion of the remainder were Arab. The HTC census also revealed that a sizeable proportion of the Herongate tenants were newcomers to Canada; and 21 of the units were homes to people who were receiving support from the Rent Geared to Income (RGI) program in the city (HTC, 2018).

\section{Theoretical Grounding}

This section sets the theoretical context by discussing our conception of social justice, together with our views on why social injustice persists in Canada and around the world, drawing primarily on the works of Rawls (1971) and Dorling (2015), respectively.

\section{Theorizing Social Justice: The Rawlsian Approach}

Given the diversity of perspectives underpinning the regulation of social (in)justice, it is unsurprising that the theorization of social justice remains an area of intense debate. Different principles yield different theories, with varying emphasis on themes such as desert, merit, entitlement, equality of opportunity, and equality of outcomes. Perhaps the most substantive contemporary theory of social justice comes from the work of John Rawls (1971), who sees social justice as a demand for fairness. Even though it is virtually impossible to do justice to the Rawlsian theory of "justice as fairness," it is still worthwhile to identify its salient features to help ground our ensuing discussion properly.

Any fair distribution of benefits and burdens of society is expected to entail equality. However, equality means different things to different people, with some seeing it in terms of equal distribution of outcomes and others in terms of equal distribution of opportunities. Rawls (1971) made a ground-breaking contribution to the debate on the relationship between social justice and equality with his emphasis on fairness. His theory starts with a thought experiment in which people find themselves in an "original position" from which they are working together to form a new society. How do individuals in this original position establish the principles of justice for their new society? To address this questions, Rawls uses his famous metaphor of a "veil of ignorance" to postulate a situation in which all those who form the new society are ignorant of their place in it: they do not know their own background characteristics such as age, class, creed, place of birth, and gender. Rawls argues that to be fair is to be impartial, and the most reasonable way to be impartial, in his view, is to operate behind a veil of ignorance. The overarching argument here is a simple one: even though we 
might want to promote our self-interest, because we do not know our own place in society, we will play it safe and ensure that no one group is disadvantaged in order to give advantage to another group.

By far the most important aspect of Rawls's (1971) theory for our present study is his difference principle, which posits that inequality in the distribution of scarce goods and services is justified if and only if it serves to increase the advantage of the least favoured groups in society. This is how Rawls describes the application of the difference principle:

In applying it, one should distinguish between two cases. The first case is that in which the expectations of the least advantaged are indeed maximized... The second case is that in which the expectations of all those better off at least contribute to the welfare of the more unfortunate. (p. 78)

Invariably, the Herongate situation has "winners" and "losers," with serious social justice implications, which are clearly amenable to a Rawlsian analysis. Drawing on the difference principle, we urge the powers-that-be to review all aspects of the case to see whether or not the mass eviction stands to increase or decrease the advantage of the least favoured group. Rawls' (1971) difference principle requires us to make the worst-off members of society as well-off as possible in our social justice estimation. In the next section, we examine why social injustice and inequality persist even in a rich country such as Canada, drawing on the work of Dorling (2015).

\section{Why Social Injustice and Inequality Persist: Insights from Danny Dorling}

Regardless of where one stands in theorizing social (in)justice and inequality, we all have good reasons to appreciate Danny Dorling's (2015) recent contribution to the discussion through his book Injustice: Why Social Inequality Still Persists. In this book, Dorling examines the myths that sustain inequality in society. According to Dorling, inequality persists because of five main myths, including the beliefs that elitism is efficient, exclusion is necessary, prejudice is natural, greed is good, and despair is inevitable. As Sam Pizzigati (2015) points out in his prologue to Dorling's book, "we have simply imbibed too many myths from those who lord over us" (p. xvi); and Dorling's effort is to cut through these myths to help ameliorate the situation.

According to Dorling (2015), one of the enduring myths that sustain inequality is the belief that elitism is efficient, and that people get to the top through meritocracy. Feeding into this myth is the idea that the elite are, perhaps, a gift to others, who should be grateful for the elite's talents and rewards. In Dorling's view, people are very similar in ability, and for the elite to think that they are perhaps superhuman - without acknowledging the intergenerational transmission of privileges, wealth, and other advantages misses the point, and, indeed hurts not only the poor but also the elite themselves. 
Another myth that sustains inequality, according to Dorling (2015), is the belief that exclusion is necessary. In a way, this myth emanates from the first one, as elitism is often used to justify exclusion. As inequality widens through elitism, social and spatial exclusions become commonplace. The third myth in Dorling's account is the belief that prejudice is natural, which is, in turn, a derivative of the preceding two. As he puts it:

Elitism and exclusion have further causes and corollaries, and the chief among these is prejudice. As elitism and inequality rise, and as more people become socially excluded... those at the top more often look down on others with ever greater distain and, at the same time, with fear, as evidenced by growing social segregation. (p. 8)

The idea that prejudice engenders fear is worthy of note here, since it underpins much of the racism and Islamophobia that undermine the wellbeing of racialized people in many Western countries, including Canada. The next myth exposed by Dorling (2015) concerns the belief that greed is good. Dorling traces the greed that led to the financial crisis of 2008, for example, to the rise of elitism, exclusion, and prejudice in the preceding years. Dorling notes that "by late 2014, chief executives of UK FTSE 100 firms were paid, on average, 342 times more than their minimum wage employees" (p. 233). Needless to say, the situation in Canada is not much different.

The final myth presented by Dorling (2015) concerns the belief that despair is inevitable. There are indications that despair (in many of its guises, including fear, mistrust, uncertainties, anger, stress, and depression) has increased in recent years, as intra- and inter-national inequalities widen. As Dorling rightly notes, "human beings are not mentally immune to the effect of rising elitism, exclusion, prejudice and greed. They react like rats in cages to having their social environments made progressively more unpleasant... the greater the dose of inequality, the higher the response in terms of poor mental health" (p. 305). Dorling urges us not to give in to despair as though it is inevitable, for it is not.

What lessons can we glean from Dorling's (2015) work for our examination of the Herongate situation? Media accounts suggest that the corporate landlord of the Herongate complex is planning to upgrade the property for a more affluent clientele of tenants. Clearly, then, some elitism is implicated in the endeavour, as the planned eviction is to benefit the owner, as well as those in the top end of the housing market. Similarly, the eviction entailed exclusion, since the plan is to replace the former low-income tenants with affluent tenants. Also, there is some prejudice involved to the extent that most of the evicted tenants were minorities, the majority of whom are Black and Muslims who routinely encounter racism and Islamophobia in Canada. Moreover, the planned upgrade, and the rent hike that would invariably come with it, points to some selfish desire or greed (justified or not) on the part of the owner. From Dorling's work, we are convinced these dynamics are 
neither inevitable nor justified, and neither is the despair they engender for the individual and the collective.

\section{Understanding Housing Discrimination and its Prevalence in Canada}

Housing discrimination is a social practice in which individuals or families are treated unfairly in their effort to access or retain housing, based on their background characteristics, such as race, ethnicity, social class, gender, disability, or sexual orientation (Lemert, 2011, p. 146; Scott \& Marshall, 2009 , p. 189). Thus, housing discrimination is not limited to unfair treatment in accessing housing in a particular building or location; it also involves prejudicial treatment in retaining housing. Clearly then, there are exclusionary and non-exclusionary dimensions to housing discrimination. The former connotes "actions and practices that exclude an individual or a family from obtaining the housing of their choosing [while the latter]... refers to discriminatory actions that occur within an already established housing arrangement" (Roscigno et al., 2009, p. 52).

There is considerable evidence to show that housing discrimination exists in Canada, and this is unsurprising, given the prevalence of discrimination in Canadian society, especially as it pertains to racialized people in employment, education, and law enforcement (James, 2012; Tanovich, 2006; Tator \& Henry, 2006). The common methodologies used to determine whether housing discrimination exist or not include housing discrimination audits or paired-testing methods, quantitative surveys, and qualitative interviews. With housing discrimination audits, two people - normally one White and the other a visible minority - pose as equally qualified home seekers, inquire about the availability of apartments or homes, and record their respective experience regarding whether they were called back, whether they ware told the unit was (un)available, whether they were required to pay any fee or deposit, etc.

Even though paired-testing studies are uncommon in Canada, some noteworthy ones exist, including the pioneering works of Chandra (1973) in Montreal; the Manitoba Association of Rights and Liberties (1981) in Winnipeg; Garon (1988) in Montreal; and Henry (1989) in Toronto. A more recent paired-testing study was conducted by the Center for Equality Rights in Accommodation (2009), which found significant levels of discrimination against all five groups studied: lone parents, Blacks lone parents, people with mental illness, South Asians, and people on social assistance.

In addition to this paired-testing research, there are numerous studies in Canada that rely on either quantitative surveys or qualitative interviews, or both, in cities such as Montreal, London, Winnipeg, Ottawa and Toronto, with the latter featuring most prominently (Hulchanski, 1993; Hulchanski \& Weir, 1992; Mensah \& Williams, 2014; Murdie, 1994, 2002, 2003; Owusu, 1996; Teixeira, 2006, 2008). While many of these studies deal exclusively 
with a particular ethno-racial group, some of them examine how two or more groups compare with each other, with African immigrants featuring quite frequently in these comparisons. For instance, Murdie (2002) compares the housing discrimination faced by Somalis and Polish immigrants in Toronto; Mensah and Williams (2014) compare the cultural dimensions of the housing problems and discrimination faced by Ghanaians and Somalis in Toronto; and Teixeira (2008) compares the housing problems faced by Angolans, Mozambicans, and Cape Verdean immigrants in Toronto. Teixeira's (2008, p. 253) findings indicate that the darker the skin colour of the African immigrant, the greater the risk of discrimination in the rental market.

Clearly, there are studies pointing to the prevalence of housing discrimination in cities such as Toronto and Montreal, but is there any evidence of housing discrimination in Ottawa? Our extensive literature search uncovered only a few such studies in Ottawa. Still, the limited number of studies on housing discrimination in Ottawa should not be taken as evidence of no housing discrimination in Ottawa. There could be other reasons for this lacuna, including the lack of interest in such a controversial topic among mainstream Canadian social scientists and the dearth of a critical mass of ethno-racial minority scholars to tell their own stories. Meanwhile, given the prevalence of discrimination in many spheres of life in Canadian cities, including Ottawa (Daigle, 2017; Mohamed, 2007; Social Planning Council of Ottawa, 2008), it is hard to see how Ottawa could be immune from housing discrimination.

One of the first studies on housing discrimination involving Ottawa was conducted by the Canadian Civil Liberties Organization (CCLO) in 1976, and published in 1977 by Alan Borovoy. In this study, the CCLO examined whether real estate agents in Toronto, Hamilton, London, Windsor, and Ottawa were willing to discriminate on behalf of a fictitious family, which purportedly wanted to sell its home, but only to a White person. The findings indicate that "of the 30 agents surveyed, $90 \%$ agreed to comply with the 'gentleman's agreement' to discriminate" (Borovoy, 1977, as cited in Novac et al., 2002, p.16). In another study in Ottawa, Rupert (1997) found that as many as 60 neighbours mounted a campaign to oppose the opening of a group home for teenagers under the care of the Children's Aid Society of Ottawa. In a related study, Hodan Mohamed (2007) examined the settlement and integration challenges of Somali single mothers in Ottawa, together with their health implications. She found that the women experienced race-based discrimination and social exclusions in their efforts to settle in Ottawa, and that many of their mental health problems were underpinned by racial discrimination in employment and housing. 


\section{Ethno-racial Enclaves: Exploring their Formation and (De)merits}

From the standpoint of social theory, "ethnicity" is a socially constructed attribute of individuals or groups based on their culture or nationality. Members of an ethnic group, therefore, share a common cultural heritage (Macionis \& Gerber, 1999, p. 324). Ethnicity is often distinguished from "race," which is also a socially constructed attribute, but based on people's physical characteristics, such as skin colour or hair texture (Mensah, 2002, p. 16). While the two concepts are often used interchangeably, they are, indeed, different. Thus, we find some scholars (Mensah \& Williams, 2017) using the term ethno-racial to be all-embracing in an effort to avoid the conflation of the two concepts.

An "enclave" connotes the spatial concentration of a particular group within a city (Qadeer et al., 2010; Walks \& Bourne, 2006), while an "ethnic enclave" implies the spatial concentration of an ethnic group and its cultural institutions and businesses (Qadeer et al., 2010). Another closely related concept is that of a "ghetto." While "ethnic enclave" and "ethnic ghetto" are related, they are different because of their disparate formation. Enclaves are normally formed voluntarily by their residents, within the strictures of the housing market and prevailing institutions and norms. Ghettoes, on the other hand, are mostly formed as a result of extreme social exclusion practiced by mainstream society. Of course, there is usually outside pressure behind the formation of both ghettoes and enclaves; however, the level of pressure is more intense in the case of ghetto formation. Ethnic enclaves are generally looked upon far more favourably by outsiders, as "positive" spaces with some benefits to their residents, compared to what ghettoes could ever offer. The available Canadian literature indicates that ghettoes, at least those that are comparable to what obtain in the United States, do not exist in Canada (Murdie, 1994; Qadeer et al., 2010; Walks \& Bourne, 2006).

The spatial concentration of ethnic minorities in ethnic enclaves is often seen as a form of racial segregation, with all the pejorative connotations that the term conjures. To be sure, ethnic enclaves can undermine the integration and social mobility of some minorities. For one thing, life in the ethnic enclave undercuts minorities' effort to learn the official language of the host society, as they are constantly interacting mainly with people of their own ethnicity in their native language. Also, given the lack of local resources and employment opportunities in many ethnic enclaves, residents often endure long spells of un- and under-employment, low-income and, sometimes, problems of crime. Meanwhile, as Mensah and William (2017) note in their thought-provoking book, Boomerang Ethics:

Despite the negative perceptions of minority enclaves in the minds of some Canadians, it would be erroneous to think that there is nothing good about these places. Among other things, spatial concentration allows ethno-racial minorities to maintain their cultural values and practices, strengthen their social networks and, ultimately, enhance their intragroup social cohesion. (p. 62) 
Moreover, studies (e.g., Peach, 1996; Phillips, 2007; Walks \& Bourne, 2006) show that such clusters allow minorities to attain the requisite critical mass of population to support their economic enterprises and sociocultural institutions. More often than not, the social networks engendered by these enclaves give ethnic-owned businesses a competitive edge over other businesses operating in these spaces. Finally, ethnic enclaves provide some level of defense against racial discrimination from the majority.

\section{Urban Renewals, Gentrification, and the Mass Eviction of the Urban Poor}

The prevailing literature generally deals with large-scale demolitions and evictions in cities under the umbrella of "urban renewal," which is often used interchangeably with such terms as "urban redevelopment," "urban reconstruction," and "urban revitalization," depending on place and time. Over the years, urban renewal has been used to describe large-scale redevelopment of "the built environment in downtown and older inner-city neighbourhoods, typically undertaken by the State or more recently in the strategic form of a public-private partnership" (Ley, 2002, p. 881). Urban renewal projects were very popular from the 1950 s to the 1970 s, as they were used to change the general layout of cities by renovating and rearranging some buildings and roads (Uzun, 2003, p. 365). Indeed, since the publication of Jane Jacobs's The Death and Life of Great American Cities (1961), the use of "urban renewal" has declined, with some scholars only deploying it in the past tense, in an effort to avoid its associated baggage.

A closely related concept to urban renewal is gentrification. Ruth Glass, who coined the term gentrification in 1964, used it to describe a form of revitalization, entailing the upper-income (i.e., the gentry class) takeover of Victorian mews in London, UK (Glass, 1964). In its contemporary usage, gentrification connotes "the influx of upper- and middle-class households into an area of old homes that were previously occupied by lower-middle and low-income individuals and households" (Yeates, 1993, p. 221).

Since the global financial crisis of 2008, there is a burgeoning literature pointing to a newer form of gentrification, induced primarily by a growing financialization of the housing market (Aalbers, 2008, 2016; August \& Walks, 2018; Fields, 2014; Fields \& Uffer, 2016; Rolnik, 2013). Perhaps, the best depiction of the new gentrification is by August and Walks (2018) in their observation that:

While traditional forms of gentrification involved the conversion of rental units to owner-occupation, a new rental-tenure form of gentrification has emerged across the globe. This is driven by financialization, a new tenant protection, and declining-social housing production, and it is characterized by the replacement of poorer renters with higher-income tenants. (p. 124) 
Evidently, gentrification is taking on different shapes in different cities, and, thus, becoming difficult to pin down as a phenomenon with a clear explanation. While its older version was dominated by "mom and pop" landlords, the newer version is underpinned by globalization and the growing financialization of the economy underway, with ownership accruing to private equity funds, financial asset management corporations, and real estate investment trusts (August \& Walks, 2018).

Moreover, the new gentrification involves what August and Walks (2018) call "squeezing" and "gentrification-by-upgrading" (p. 124). With squeezing, the financialized landlords try to get as much revenue as possible from the incumbent renters. The common tactics used include rent increases; increases in ancillary fees, such as fees for parking and laundry; reduced services and maintenance; and harassment, disruptive renovations, and unwarranted evictions, as witnessed in the Herongate complex. Gentrification-byupgrading is where the financialized landlord uses a host of sophisticated asset management tactics to "upgrade, flip, and gentrify entire buildings" (August \& Walks, 2018, p. 124). The idea here is to reposition and transform the buildings to help shift their tenant base from low- to high-income people. In fact, media accounts suggest that the landlord of the Herongate complex plans to upgrade the Herongate units to "build an alignment" with Alta Vista an affluent and White community just north of Herongate ("Alta Vista Residents," 2016; "Petition," 2017). Census data indicate that Alta Vista is $80 \%$ White, with about $55 \%$ of its households having incomes of over $\$ 100,000$ per year, which is far higher than what obtained in the Herongate community, where only about five percent of the households had incomes of over $\$ 100,000$ by the 2016 census.

Clearly, regardless of their causes, gentrification and mass evictions are exercises in displacement. The fact that neighbourhoods in and around the inner city tend to attract such projects too is quite telling in the context of the power differentials between the displacers and the displaced After all, the inner city is where the advantages of proximity and easy access to historic attractions are often found; why wouldn't those with power manoeuver for such spaces at the expense of low-income people with no power? Relatedly, given the empirically verifiable overlap between race, class, and space in urban Canada (Mensah \& Williams, 2017), and more so in the United States, it is unsurprising that such low-income neighbourhoods are mostly inhabited by ethno-racial minorities and new immigrants who generally struggle to find housing outside of the neighbourhood, due both to their exposure to housing discrimination and their lack of financial resources. 


\section{The Struggle for Housing at Herongate: Insights from Rawls and Dorling}

Dorling (2015) observes that "if you had to choose one word to epitomise the nature of human society as it is currently arranged worldwide, there is no better word than injustice" (p. 6). Regardless of how one looks at gentrification and mass evictions, they often entail injustice of one form or another. Some people are bound to gain, while others lose, depending on the context of who is doing the eviction and what options are available to the parties involved based on their respective socioeconomic and political power. The benefits of such projects may include increased revenues from the replenished housing stocks and the attendant increase in property tax, as well as access to improved amenities in the neighbourhood. For the most part, the new residents (most of whom tend to have more disposable income than the incumbent tenants) demand more upscale goods and services, resulting in what Lees et al. (2007, p. 131) have dubbed "boutiqueification."

At the same time, not only are the incumbent tenants "forced to find alternative housing, but they also face the emotional impact of removal from social networks and familiar community structures" (Murdie \& Teixeira, 2011, p. 73). Moreover, such large-scale evictions tend to affect low-income people more, since they find it difficult to acquire alternative housing in other parts of the city. The situation is even more damaging if the victims are racial minorities for whom housing discrimination is a reality in most cities in Canada. As the preceding paragraphs show, most of the tenants evicted from the Herongate complex are Somalis and other visible minorities, who are, susceptible to housing discrimination. Moreover, the work of Mensah and Williams (2014) shows that Somali immigrants, in particular, often live closer to their mosques to allow them to participate in their religious practices, including praying five times daily. Additionally, Somalis and other Muslims prefer to live in their ethnic enclaves where they can easily procure religion-sanctioned (halal) food, and where women can wear hijab freely without condescending looks from outsiders. Even the fact that some Islamic sects disallow their members to borrow money with interest payments makes it difficult for them to acquire mortgage in the mainstream banking system, thereby undermining their home ownership. Add to these challenges large household sizes - especially among Somalis (Mensah \& Williams, 2014) and their need for prayer rooms and gendered spaces within their homes, and one would appreciate the unique difficulties that Somalis and other Muslims evicted from Herongate encounter in their search for affordable housing.

What would Rawls and Dorling say about the Herongate situation? How do we reconcile the competing interest of the tenants and the landlord in the context of social justice? What does the Herongate situation tell us about the urban citizenship and sense of belonging of the evicted tenants, particularly given that most of them look different and come from far away lands? Should the evicted tenants be compensated, and if so by how much, knowing very 
well that the poor, beset with income insecurity, can be easily enticed to accept low cash payments? Undoubtedly, some of the evicted tenants may be able to afford their relocation with or without any support. However, for most of them, the eviction is simply too much to bear, not only because of the financial cost, but also because of the attendant emotional and health consequences (Fullilove, 2001, 2004; Goetz, 2011; Paradis et al., 2014; Shah, 2013). As Fullilove (2004) observes, by destroying their individual and collective identities and their social networks, such displacements shake up, if not destroy, the basic roots of the displaced and their communities.

With the difference principle, Rawls (1971) entreats us to operate in ways that increase the advantage of the truly disadvantaged in terms of money, power, and access to scarce resources. Compared to the landlord and the potential gentrifiers, the evicted Herongate tenants are the least favoured, and thus deserve preferential treatment. Adherence to the difference principle can come in many ways, ranging from the status quo to different levels of compensation aimed at a reasonable amelioration of the monetary, emotional, and health cost to the victims. With the Herongate tenants protesting against their eviction, it follows that they would like to be reinstated; thus, from the standpoint of the difference principle, it would be prudent to take their request to return seriously. Should this demand be too much for the landlord to bear, then different levels of compensation should be on the table for the tenants. With the difference principle, Rawls draws our attention to the moral power and obligation that people have regarding their sense of justice. Similarly, Sen (2009) argues that "if someone has the power to make a change that he or she can see will reduce injustice in the world, then there is a strong social argument for doing just that" (p. 205). If one accepts this argument, as we do, then it follows that people with power should neither operate in their self-interest alone nor on the basis of mutual interest, but, indeed, go further to address the unilateral obligation that comes with the asymmetry of power they wield in society. Evidently, both Rawls and Sen recognize the obligations of power and the need for the powerful to do more to advance the wellbeing of the poor and marginalized to reduce injustice.

From the work of Dorling (2015), we know that injustice is not inevitable; after all, hegemony breeds its own counter-hegemonic movement. Accordingly, the Herongate community and its supporters should be encouraged to resist the eviction, or pursue the commensurate compensation to redress the monetary, emotional, and health costs implicated in the eviction. To the extent the social justice advocacy is at its core moralistic, what forms of resistance are ethically permissible? What can the evictees of Herongate demand from the landlord and civic authorities, without infringing on moral sensibilities? Notwithstanding - or, perhaps, because of - the moral imperatives of social justice advocacy, the Herongate protestors should not be faulted for their outrage. As Sen (2009) poignantly reminds us, resistance to injustice is not only based on sound argument but it also draws on indignation (p. 390). Still, among the most prudent approaches opened to the Herongate 
protesters are open-minded engagements with the housing gatekeepers; petition-imbued public protest; and legal action, without any inclination toward physical violence and the destruction of property.

\section{The Herongate Situation: The Right to Housing and the Regulation of} Mass Evictions

The Herongate tenants and their allies engaged in various forms of resistance, including lobbying politicians, public protest, and legal action. Still, they were displaced and only minimally compensated. Though some were able to relocate within the neighbourhood, many others moved to disparate neighbourhoods and lost their connection to the Herongate community. Even if some of the Herongate tenants are eventually afforded the right to return to the new development, which is one of the legal remedies some of them have requested from the Human Rights Tribunal of Ontario, they will never be fully compensated for the substantial disruption to their lives or the erosion of their community.

One way to realize greater justice in development projects like Herongate is to recognize a right to housing in Canada. This right is enshrined in several international covenants, most notably Article 11 of the International Covenant on Economic, Social and Cultural Rights (ICESCR), to which Canada is a signatory. The ICESCR's broad guarantee of housing rights has been interpreted to include specific protections against mass evictions for large development projects. The institution tasked with reporting on and advancing the rights enshrined in the ICESCR, the UN Committee on Economic, Social and Cultural Rights, elaborated on specific rights with respect to evictions in its General Comment Numbers 4, the Right to Adequate Housing, and 7, the Right to Adequate Housing: Forced Evictions (Kothari, 2007). These rights include a right for tenants to be consulted on large-scale development projects that threaten to displace them, and a right to return or permanent resettlement upon project completion. In 2007, the UN Special Rapporteure published the Basic Principles and Guidelines on Development-Based Evictions and Displacements, which enjoins states to ensure, among other protections, that those displaced in mass evictions carried out for the purposes of large-scale development may return upon project completion (Kothari, 2007).

Although the ICESCR has been signed and ratified by Canada, it is yet to be implemented by Parliament into domestic law. The absence of a domestic law enshrining a right to housing means that although Canada has committed itself internationally to upholding that right, there is no domestically judiciable law to make it meaningful and enforceable, despite an impressive, yet ultimately unsuccessful, attempt to have it read into sections 7 (right to life, liberty, and security of the person) and 15 (right to equality) of the Charter of Rights and Freedoms in the context of Charter litigation in 
Tanudjana v. Canada (Attorney General), 2014 ONCA 852. To date, whether section 7 of the Charter guarantees a right to housing, or whether it imposes any other positive obligation on the state to take action (rather than merely restraining state action), is subject to an ongoing legal debate (Cottrill, 2018, p. 84; Heffernan et al., 2015, p. 30). In the absence of a justiciable right to housing in Canada, there is no general right of return for tenants evicted en masse for the purposes of real estate redevelopment. ${ }^{2}$

It was not entirely fanciful for Timbercreek to assume that it could redevelop Herongate from an affordable to luxury rental complex without encountering major legal obstacles, such as the right to housing. In its eviction of Herongate residents, Timbercreek complied with the Residential Tenancies Act, which regulates evictions in Ontario, and it otherwise followed municipal regulations for demolitions and property development. Although the manner in which Timbercreek pursued its development violates international law, it could do so with impunity in the absence of a corresponding domestic law to stop it. A right to housing per se is therefore not being asserted in the legal challenge launched by the Herongate Tenants Coalition in the Human Rights Tribunal of Ontario in Various Applicants $v$. Timbercreek Asset Management Inc., et al. - HRTO File Numbers : 201936509-1 to 2019-36523-I. Rather, the application advances novel arguments based on the anti-discrimination provisions of the Human Rights Code of Ontario, maintaining that it is discriminatory to displace a community composed overwhelmingly of migrants, people of colour, and people sharing other personal traits protected by the Code, in order to replace it with a community of affluent whites.

Even if successful, the Herongate case will not result in the recognition of a general right to housing in Canada. Although the Herongate tenants' application argues in favour of a right to housing, that right is not being advanced as the robust, constitutionally enshrined right that it was in Tanudjaja (although the Herongate case could help lay the groundwork for such a right in a subsequent case). Rather, the application argues that where a violation of the right to housing, such as mass eviction without consultation or the right to return, creates a discriminatory impact by adversely affecting people because of their race, colour, and ethnicity, among other grounds, then the Human Rights Code has been violated. Put another way, the argument is that when a landlord develops its property, it is required by the Code to ensure the development does not discriminate against people because of their race, skin colour, or other personal traits protected by the Code. If the application is successful, the practical consequence will be that developers in Ontario would be prohibited from acquiring a predominantly immigrant or racialized neighbourhood, and then evicting everyone for the purpose of developing upscale rental housing or condos to rent to more affluent whites.

\footnotetext{
${ }^{2}$ The notable exception is Toronto, and possibly other municipalities in Canada, which have bylaws that empower the city to impose a right of return in certain circumstances.
} 
However, the rights being asserted in the Herongate case are not a perfect substitute for a universal right to housing. They are an effective workaround for some, at best. What if, for example, a developer takes over a poor white working-class neighbourhood, evicts everyone, redevelops the property and then rents to more affluent whites? Discrimination based on poverty or economic status is not prohibited by the Code. So a mass eviction in those circumstances is not prohibited because of the absence of racial, ethnic, or other form of discrimination prohibited by the Code.

But should not the right to be free from arbitrary eviction be guaranteed to everyone, including working class whites? If so, what would those rights look like? How could they be enforced? More robust and meaningful housing rights, and greater social justice in housing, are possible. A justiciable right to housing has been implemented in other jurisdictions internationally, in some cases with admirable results (see, for example, King, 2015). An exhaustive list of states that have enshrined a right to housing in law is beyond the scope of this article, but noteworthy examples include South Africa, Scotland, and France. These countries and others have, to varying degrees, implemented the housing rights enshrined in the ICESCR and ancillary documents. South African courts, for example, have recognized a specific right of persons being displaced by large development projects to meaningful engagement and mandatory consultation (Chenwi, 2015, pp. 78-80). Had the right to housing been implemented in Canada, the Herongate evictions may have looked much different.

\section{Conclusion}

Forms of capital absorption in cities, including gentrification and mass evictions, are dialectical processes, and thus entail creative destruction or destructive creation. As such, these processes often have "losers" and "winners;" and to the extent that they also have class and racial dimensions, it is not hard to realize that it is the "poor, the underprivileged and those marginalized from political power that suffer first and foremost" (Harvey, 2008 , p. 33). It is clear from the preceding discussion that housing discrimination is real in urban Canada. Additionally, it is evident that, unlike the formation of ghettoes in the US, where extreme external pressures are involved, ethnic enclaves, such as the Herongate Community in Ottawa, come about mainly because they conform, at least in part, to the needs of the minority group in question. Even though such segregated spaces often engender negative connotations in the minds of outsiders, they help the minority residents to sustain their cultural values, strengthen their social capital and social cohesion, and ultimately promote their settlement and integration in the host country. Clearly, then, mass evictions of minority populations from their enclaves do not only take a monetary toll on residents, 
but they also exact considerable emotional, psychological, and health consequences - all of which have social justice implications.

With insights from Rawls (1971) and Dorling (2015), we noted that it is about time that landlords seeking mass evictions paid due attention to the well-being of the incumbent tenants, especially when the tenants are lowincome minorities who are likely to face extreme difficulties in finding housing outside of their enclave. Thus, mass eviction decisions should not be informed by raw economic considerations alone, for there are always some underlying ethical issues to be addressed. For one thing, if renovations lead to improvement in the housing stocks, and even yield profit for the city, developer, and landlord, at the expense of the vulnerable, weak, and poor members of society, then what are we to make of the moral sensibilities of our society? Moreover, how are we to protect the interests of the powerless against those of the powerful? Rawls, for one, would expect us to maximize the wellbeing of the powerless relative to the powerful in such situations. And from Dorling's work we know that resistance and counter-hegemonic advocacy in such situations are worthwhile, since, in his view, injustice and despair are neither justified nor inevitable. Meanwhile, as demonstrators and social movement activists bring their loud laments about these mass evictions to the public, it is uncertain whether their opposition will be sustainable enough to produce any meaningful and mutually agreeable solution. Still, there is hope, for urban resistant movements are increasingly going global, with supporters and signs of rebellion coming from far and wide places with the aid of social media. In addition to the pressures exacted by urban resistant movements and the insights drawn from the works of Rawls and Dorling, federal, provincial, and municipal governments have a role to play to resolve this social (in)justice. A clear policy suggestion from the preceding discussion is for the federal government to pass a domestically judiciable law - in consonance with the International Covenant on Economic, Social and Cultural Rights (ICESCR) - to uphold Canadians' right to housing. Relatedly, there is the need to establish a Mass Eviction Complaints Board, of a sort, at the provincial or municipal level to help resolve the conflicting interests of the parties involved in such disputes by conducting hearings and prescribing legally binding compensations. Clearly, our approach to resolving the Herongate situation has its limitations, since it dwells mainly on the antidiscrimination provisions of the Human Rights Code of Ontario, which, obviously, does not prohibit discrimination based on social class or poverty per se. Thus, while poor Blacks can be protected by the Code, from the standpoint of their race, the same cannot be said of poor Whites. Until Canada enacts a domestically justiciable law to enforce the right to housing, the need for further research to deal with the special case of poor Whites who might fall prey to mass evictions cannot be over-emphasized. 


\section{References}

Aalbers, M. (2008). The financialization of home and the mortgage market crisis. Competition and Change, 12(2), 148-166.

Aalbers, M. (2016). The financialization of housing: A political economy approach. Routledge.

Alta Vista residents object to 'three monsters' Herongate complex. (2016, September 30). Ottawa South Weekender.

http://go.galegroup.com/ps/i.do?p=CPI\&u=queensulaw\&id=GALE|A465169944\&v=2.1\&it=r\&s id $=$ CPI\& asid $=851 \mathrm{bc} 6 \mathrm{a} 3$

August, M. \& Walks, A. (2018). Gentrification, suburban decline, and the financialization of multi-family rental housing: The case of Toronto. Geoforum, 89, 124-136.

Borovoy, A. (1977). Report on discrimination by real estate agents. Canadian Civil Liberties Organization.

Center for Equality Rights in Accommodation. (2009). Sorry, it's rented: Measuring discrimination in Toronto's rental housing market. https://static1.squarespace.com/static/5e3aed3ea511ae64f3150214/t/5e 7b7922dfdbdb3c5ec $89 \mathrm{a} 23 / 1585150243155 /$ Sorry $\% 2 \mathrm{C} \% 2 \mathrm{Bit} \% 27 \mathrm{~s} \% 2$ Brented.pdf

Chenwi, L. (2015). Implementation of housing rights in South Africa: Approaches and strategies. Journal of Law \& Social Policy, 24, 67-87.

Cottrill, E. J. (2018). Novel uses of the Charter following Doré and Loyola. Alberta Law Review, 56(1), 73-117.

Daigle, C. M. (2017). Addressing anti-Black racism in Ottawa. Ottawa Local Immigration Partnership \& City For All Women Initiative. http://www.cawiivtf.org/sites/default/files/pdf/anti-black_racism_forum_report_2017-02.pdf

Dorling, D. (2015). Injustice: Why social inequality still persists. Policy Press.

Fields, D. (2014). Contesting the financialization of urban space: Community organizations and the struggle to preserve rental housing in New York City. Journal of Urban Affairs, 37(2), 144-165.

Fields, D., \& Uffer, S. (2016). The financialization of rental housing: A comparative analysis of New York City and Berlin. Urban Studies, 53(7), 1486-1502.

Fullilove, M. T. (2001). Root shock: The consequences of African American dispossession. Journal of Urban Health, 78(1), 72-80.

Fullilove, M. T. (2004). Root shock: How tearing up city neighbourhoods hurts America, and what we can do about it. One World/Ballantine Books.

Garon, M. (1988). Une expérience de testing de la discrimination raciale dans le logement à Montréal. Commission des droits de la personne du Québec.

Glass, R. (1964). Introduction: Aspects of change. In H. B. Rodgers (Ed.), Aspects of change (pp. xii-xiii). MacGibbon \& Kee.

Goetz, E. (2011). Gentrification in Black and White: The racial impact of public housing demolition in American cities. Urban Studies, 48(8), 1581-1604.

Harvey, D. (2008). The right to the city. New Left Review, 53, 23-40.

Heffernan, T., Faraday, F., \& Rosenthal, P. (2015). Fighting for the right to housing in Canada. Journal of Law \& Social Policy, 24, 9-45.

Henry, F. (1989). Housing and racial discrimination in Canada. Policy and Research, Multiculturalism and Citizenship.

HTC (Herongate Tenants Coalition). (2018). 2018 Herongate eviction census. https://herongatetenants.ca/herongate-eviction-census/

Hulchanski, D. J. (1993). Barriers to equal access in the housing market: The role of discrimination on the basis of race and gender. University of Toronto, Faculty of Social Work and Centre for Urban and Community Studies.

Hulchanski, D. J., \& Weir, E. (1992). Survey of corporations owing or managing large numbers of rental apartments in metro Toronto: Requirement for last month's rent deposit. University of Toronto, Faculty of Social Work.

Jacobs, J. (1961). The death and life of great American cities. Vintage Books.

James, C. E. (2012). Students 'at risk': Stereotypes and the schooling of Black boys. Urban Education, 47(2), 464-494. 
Kestler-D'Amours, J. (2018, August 18). Heron Gate mass eviction: 'We never expected this in Canada'. Al Jazeera. https://www.aljazeera.com/indepth/features/heron-gate-masseviction-expected-canada-180817200106463.html

King, F. (2015). Scotland: Delivering a right to housing. Journal of Law \& Social Policy, 24(9), 154-161.

Kothari, M. (2007). Basic principles and guidelines on development-based evictions and displacement. United Nations. https://www.ohchr.org/Documents/Issues/Housing/Guidelines_en.pdf

Lees, L., Slater, T., \& Wyly, E. (2007). Gentrification. Routledge.

Lemert, C. (2011). Discrimination. In B. S. Turner (Ed.), The Cambridge dictionary of sociology (p. 146). Cambridge University Press.

Ley, D. (2002). Urban renewal. In R. J. Johnston, D. Gregory, G. Pratt, \& M. Watts. (Eds.), The dictionary of human geography (p. 881). Blackwell Publishers.

Macionis, J. J., \& Gerber, L. M. (1999). Sociology. Prentice Hall.

Manitoba Association for Rights and Liberties. (1981). Racial discrimination in housing in Winnipeg. National Committee on Human Rights.

Mensah, J. (2002). Black Canadians: History, experience, social conditions. Fernwood Publishing.

Mensah, J., \& Williams, C. (2014). Cultural dimensions on African immigrant housing in Toronto: A qualitative insight. Housing Studies, 29(3), 438-455.

Mensah, J., \& Williams, C. (2017). Boomerang ethics: How racism affects us all. Fernwood.

Mohamed, H. S. (2007). Somali single mothers in Ottawa: Challenges and opportunities of resettlement and implications for health and well-being [Master's thesis, Carleton University]. CURVE. https://curve.carleton.ca/924167c1-7880-40f6-9b70-9cc9aa9eb64f

Murdie, R. A. (1994). 'Blacks in near-ghettos?' Black visible minority population in Metropolitan Toronto Housing Authority public housing units. Housing Studies, 9(4), 435457.

Murdie, R. A. (2002). The housing careers of Polish and Somali newcomers in Toronto's rental market. Housing Studies, 17(3), 423-443.

Murdie, R. A. (2003). Housing affordability and Toronto's rental market: Perspectives from the housing careers of Jamaicans, Polish and Somali newcomers. Housing, Theory and Society, 20(4), 183-196.

Murdie, R., \& Teixeira, C. (2011). Impact of gentrification on ethnic neighbourhoods in Toronto: A case study of Little Portugal. Urban Studies, 48(1), 61-83.

Novac, S., Darden, J., Hulchanski, D., \& Seguin, A.-M. (2002). Housing discrimination in Canada: The state of the knowledge. Canada Housing and Mortgage Corporation.

Owusu, T. (1996). The adaptation of Black-African immigrants in Canada: A case study of residential behaviour and ethnic community formation among Ghanaians in Toronto [Doctoral dissertation, University of Toronto].

Paradis, E., Wilson, R. M., \& Logan, J. (2014). Nowhere else to go: Inadequate housing and risk of homelessness among families in Toronto's aging rental buildings. Cities Center, University of Toronto. http://neighbourhoodchange.ca/documents/2014/04/paradis-et-al2014-nowhere-else-to-go-inadequate-housing-risk-of-homelessness-among-families-intorontos-aging-rental-buildings-rp231.pdf

Peach, C. (1996). Good segregation, bad segregation. Planning Perspectives, 11(4), 379-398.

Petition circulating to challenge proposed Herongate development. (2017, February 21). Ottawa South Weekender.

http://go.galegroup.com/ps/i.do?p=CPI\&u=queensulaw\&id=GALE|A482060821\&v=2.1\&i $\mathrm{t}=\mathrm{r} \& \mathrm{sid}=\mathrm{CPI} \&$ asid $=\mathrm{d} 078 \mathrm{f} 918$

Philips, D. (2007). Ethnic racial segregation: A critical perspective. Geography Compass, 1(5), 1138-1159.

Pizzigati, S. (2015). Letter from America: Commentary by Sam Pizzigati. In D. Dorling (Ed.), Injustice: Why social inequality still persists (pp. xiv-xvii). Policy Press.

Qadeer, M., Agrawal, S. K., \& Lovell, A. (2010). Evolution of ethnic enclaves in the Toronto Metropolitan Area, 2001-2006. Journal of International Migration and Integration, 11(3), 315-339. 
Rawls, J. (1971). A theory of justice. Harvard University Press.

Rolnik, R. (2013). Late neoliberalism: The financialization of homeownership and housing rights. International Journal of Urban and Regional Research, 37(3), 1058-1066.

Roscigno, V. J., Karafin, D. L., \& Tester, G. (2009). The complexities and processes of racial housing discrimination. Social Problems, 56(1), 49-69.

Rupert, J. (1997, January 27). Cumberland residents latest to fight group home plan. The Ottawa Citizen, p. 33.

Scott, J., \& Marshall, G. (2009). Discrimination. In J. Scott \& G. Marshall (Eds.), Oxford dictionary of sociology (pp. 182-183). Oxford University Press.

Sen, A. (2009). The idea of justice. Harvard University Press.

Shah, M. (2013, June 8). Thorncliffe residents protest living conditions. Toronto Sun. https://torontosun.com/2013/06/08/thorncliffe-park-residents-protest-livingconditions/wcm/0c1a4629-6957-4305-8690-c4e616594dbc

Schnurr, J. (2018, May 17). Herongate residents rally to save townhomes. CTV News Ottawa. https://ottawa.ctvnews.ca/herongate-residents-rally-to-save-townhomes-1.3934585

Social Planning Council of Ottawa. (2008). Mixed blessings and missed opportunities: The intercase study on inclusion and exclusion of Ottawa's visible and ethnic minority residents. https://www.deslibris.ca/ID/219084

Statistics Canada. (2016). Census of population: Data tables. Statistics Canada Catalogue no. 98400-X2016184. https://www12.statcan.gc.ca/census-recensement/2016/dp-pd/dt-td/Rpeng.cfm

Tanovich, D. M. (2006). The colour of justice: Policing race in Canada. Irwin Law.

Tator, C., \& Henry, F. (2006). Racial profiling in Canada. University of Toronto Press

Teixeira, C. (2006). Housing experiences of Black Africans in Toronto's rental market: A case study of Angolans and Mozambican immigrants. Canadian Ethnic Studies, 38(3), 58-86.

Teixeira, C. (2008). Barriers and outcomes in the housing searches of new immigrants and refugees: A case study of 'Black' Africans in Toronto's rental market. Journal of Housing and the Built Environment, 23(4), 253-276.

Uzun, C. N. (2003). The impact of urban renewal and gentrification on urban fabric: Three cases in Turkey. Tijdschrift voor Economische en Sociale Geografie, 94(3), 363-375.

Walks, A. R., \& Bourne, L. S. (2006). Ghettos in Canada's cities? Racial segregation, ethnic enclaves and poverty concentration in Canadian urban areas. The Canadian Geographer, 50(3), 273-297.

Yeates, M. (1993). The North American city. Harper Collins. 